\title{
Effect of Irrigation with Magnetized Water on Some Vegetative and Flowering Parameters of Wheat (Triticum aestivum L.) Cultivar IPA 99
}

\author{
${ }^{1}$ Muthik A. Guda, ${ }^{1}$ Azhar Sh. Younus, ${ }^{2}$ Attyaf J.T. Altamimi, ${ }^{1}$ Aseel F. Ayoub, \\ ${ }^{3}$ Shaymaa Ma. Al Regawi, ${ }^{1}$ Aboothar H.M. Al-Edhari and ${ }^{1}$ Faris J. Alduhaidahawi \\ ${ }^{1}$ Department of Environment, \\ Muthikabd1@gmail.com,07702793409 \\ ${ }^{2}$ Department of Biology, \\ ${ }^{3}$ Department of Geology, Faculty of Science, University of Kufa, Najaf, Iraq
}

\begin{abstract}
Growth parameters data were used in this study for the evaluation of the response on some vegetative and flowering parameters of wheat shoots (Triticum aestivum L.) Cultivar IPA 99 of growth to irrigation with magnetized water and no magnetized water, afield experiment was carried out during Winter season of 2016-2017 at the farm of Technical Institute Kufa field, College of Science and University of Kufa. A randomized complete block design by split plots arrangement was used with three replications. The main plot included two levels of river water and ground brackish water while the subplot included four levels of magnetic water strength $0,750,1500$ and 3000 GUOS. The results showed that significant effect of magnetized irrigation water on all growth characteristics of wheat in both levels of water caused greater increased on) height of shoot $(\mathrm{cm})$, single leaf area $\left(\mathrm{cm}^{2}\right)$, fresh weight of shoot $(\mathrm{g})$, dry weight of shoot $(\mathrm{g})$, number of tillers, number of leaf, height of spike $(\mathrm{cm})$, weight of spike $(\mathrm{g})$, number of florets per spike (as compared with no magnetized water. Irrigation with magnetic water in 1500 GUOS give as the better results in all growth characterized. The stimulatory impact of magnetic water induced no significant marked between irrigation of magnetized river water and ground brackish water. In another way irrigation with magnetic water showed greater increased on growth characteristics and spikes initiation of wheat as compared with irrigation of no magnetized river water and ground brackish water. The results showed that significant effect of magnetized irrigation water and irrigation with magnetic water in 1500 GUOS gave the better results in all growth characterized.
\end{abstract}

Key words: Vegetative, parameters, block design, height of spike, weight of spike, number of flours

\section{INTRODUCTION}

Physical methods for plants growth stimulation is getting more popular due to the less harmful influence on the environment. The water treated by the magnetic field or pass through a magnetic device called magnetized water (Aladjadjiyan, 2010). When water is magnetized, some physical and chemical properties changed that may be causing changes in shoot characteristics, growth and production. Magnetic water treatment has found to have a pronounced effect on plants productivity (Maheshwari and Grewal, 2009) suggested that there are possibly some beneficial effects of the magnetic treatment of irrigation water for plant yield and water productivity. Moreover, magnetized water for irrigation is recommended to save irrigation water (Mostafazadeh-Fard et al., 2011) and increasing yield (Mulook et al., 2011). The results by Grewal and Maheshwari (2011) showed magnetic treatment of irrigation water and magnetic treatment of seeds had the potential to improve the early seedling growth and nutrient contents of seedling. Utilization of magnetized water improved quantity and quality of common bean crop. Irrigation of common bean plants with magnetic water increased significantly the growth characteristics, potassium, photosynthetic pigments (chlorophyll a, b and carotenoid), photosynthetic activity and translocation efficiency of photo assimilates as compared with control plants (Moussa, 2011). It was detected that the magnetic field stimulated the shoot development and led to increase of germinating energy, fresh weight and shoot length of maize (Aladjadjiyan, 2012). Qados and Hozayn (2010a, b) reported that growth parameters and yield components of wheat plants is concomitantly increased when wheat plants irrigated with magnetic water (Harichand et al., 2002). The reported that exposure of magnetic field increased shoot height, seed weight per spike and yield of wheat. There is competition for water by the agricultural, domestic and industrial users during the dry season, so, there is need to conserve and optimal use of available water.

Corresponding Author: Muthik A. Guda, Department of Environment, Faculty of Science, University of Kufa, Najaf, Iraq, Muthikabd1@gmail.com,07702793409 
Table 1: Effect of river and magnetized river water on growth characteristics of wheat

\begin{tabular}{|c|c|c|c|c|}
\hline \multirow[b]{2}{*}{ Growth characteristics of wheat } & \multirow[b]{2}{*}{ Ordinary river water } & \multicolumn{3}{|c|}{ Magnetized river water } \\
\hline & & 750 GUOS & 1500 GUOS & 3000 GUOS \\
\hline Height of plant $(\mathrm{cm})$ & 60.2 & $65.4^{\text {ns }}$ & $66^{*}$ & $64.4^{* * *}$ \\
\hline Number of leaves & 4.3 & $4.8^{\text {ns }}$ & $4.9^{\mathrm{gs}}$ & $4.5^{\mathrm{ns}}$ \\
\hline Number of tillers & 1.2 & $1.3^{\mathrm{ns}}$ & $1.7^{*}$ & $1.6^{*}$ \\
\hline Single leaf area $\left(\mathrm{cm}^{2}\right)$ & 24.4 & $30.7^{* * *}$ & $51.5^{* *}$ & $23.6^{\text {ns }}$ \\
\hline Fresh weight of shoot (g) & 1.7 & $1.8^{*}$ & $2.8^{* * *}$ & $2.6^{* * *}$ \\
\hline Dry weight of shoot (g) & 0.4 & $0.4^{\mathrm{ns}}$ & $0.7^{*}$ & $0.6^{*}$ \\
\hline Length of spike $(\mathrm{cm})$ & 10.1 & $11.2^{*}$ & $14.7^{* * *}$ & $10.6^{\text {ns }}$ \\
\hline Number of floret per spike & 23.8 & $22.4^{\text {ns }}$ & $26^{*}$ & $19.5^{\text {ns }}$ \\
\hline Weight of spike (g) & 0.7 & $0.8^{*}$ & $1.2^{* * *}$ & $0.8^{*}$ \\
\hline
\end{tabular}

Table 2: Effect of ground brackish and magnetized ground brackish water on growth characteristics of wheat

\begin{tabular}{|c|c|c|c|c|}
\hline \multirow[b]{2}{*}{ Growth characteristics of wheat } & \multirow[b]{2}{*}{ Ordinary ground brackish water } & \multicolumn{3}{|c|}{ Magnetized ground brackish water } \\
\hline & & 750 GUOS & 1500 GUOS & 3000 GUOS \\
\hline Height of plant $(\mathrm{cm})$ & 58 & $62.0 \mathrm{~ns}$ & $65.6^{* * *}$ & $63.6^{* * *}$ \\
\hline Number of leaf & 4.2 & $4.1 \mathrm{~ns}$ & $4 \mathrm{~ns}$ & $4.8 \mathrm{~ns}$ \\
\hline Number of tillers & 1.1 & $1.1 \mathrm{~ns}$ & $1.3 \mathrm{~ns}$ & $1.5^{*}$ \\
\hline Single leaf area $\left(\mathrm{cm}^{2}\right)$ & 18 & $33.9^{* * *}$ & $40.5^{* * *}$ & $19.4^{*}$ \\
\hline Fresh weight of shoot $(\mathrm{g})$ & 1.2 & $2^{* * *}$ & $2.8^{* * *}$ & $2.7^{* * *}$ \\
\hline Dry weight of shoot (g) & 0.4 & $0.5 \mathrm{~ns}$ & $0.7^{* * *}$ & $0.5^{* * *}$ \\
\hline Length of spike $(\mathrm{cm})$ & 9 & $10.5^{* * *}$ & $11^{* * *}$ & $10.5^{* * *}$ \\
\hline Number of floret per spike & 19.2 & $19.6 \mathrm{~ns}$ & $22 *$ & $20.7^{*}$ \\
\hline Weight of spike (g) & 0.3 & $0.8^{* * *}$ & $0.9^{* * *}$ & $0.8^{* * *}$ \\
\hline
\end{tabular}

$*$ *** $\mathrm{t}$-sign is significant at the 0.05 and 0.01 levels, respectively, ns: non-significant

\section{MATERIALS AND METHODS}

In order to evaluated the effects of magnetized water on wheat (Triticum aestivum L.) cultivar IPA 99 grown to irrigation with magnetized water and no magnetized water, a field experiment was carried out during Winter seasons of 2016-2017. A randomized complete block design by split plots arrangement was used with three replications. The main plot included two levels of river water and ground brackish water while the subplot included four levels of magnetic water $0,750,1500$ and 3000 GUOS.

Magnetized irrigation water on all growth characteristics of wheat in both levels of water caused greater effect on height of shoot $(\mathrm{cm})$, single leaf area $\left(\mathrm{cm}^{2}\right)$, fresh weight of shoot $(\mathrm{g})$, dry weight of shoot $(\mathrm{g})$, number of tillers, number of leaf, height of spike $(\mathrm{cm})$, weight of spike (g), number of florets per spike as compared with irrigation of no magnetized water as compared with irrigation of magnetized river water and ground brackish water.

The mean annual rainfall and seeds without visible defect, insect damage and malformation were surface sterilized using 5\% sodium hypochlorite solution for $5 \mathrm{~min}$ and then rinsed 3 times with sterile distilled water. Afterwards seeds sown in Technical Institute Kufa field, decomposed manure and farm soil sowing date was 17 th Nov. 2016 and then half of the field were irrigated twice awake with river water while the other were irrigated with the ground brackish water, the subplot irrigated after magnetization through passing in magnetic device which was connected to the water pipe (cylindrical, weight $118 \mathrm{~g}$, length $2.5 \mathrm{~cm}$, outer and inner diameter 4.4 and $3.4 \mathrm{~cm}$, respectively). Four levels of magnetic water strength $0,750,1500$ and 3000 GUOS. Magnetizations are presented in Table 1. Same treated replicated with ground brackish water (Table 2).

At 120 days after sowing, measured on sunny days between 11:00 and 12:00 $\mathrm{h}$ on the youngest fully expanded leaves using a portable leaf, leaf area was calculated using formula, leaf area $=$ leaf length ${ }^{*}$ leaf width, fresh and oven dried weight (at $75^{\circ} \mathrm{C}$ for $48 \mathrm{~h}$ ) of leaves, stem and spike were also determined. Other measurement methods of the shoots are given in Table 1 and 2. Statistical analysis was conducted using MSTAT-C program. A student test (t-test) was done to examine the significance between magnetic and non-magnetic water treatments of measured traits.

\section{RESULTS AND DISCUSSION}

Results on Table 1 showed that irrigation with magnetized river water increased height of plant $(65.4,66$, $64.4 \mathrm{~cm})$ number of leaves $(4.8,4.9,4.5)$, number of tillers $(1.3,1.7,1.6)$, single leaf area $\left(30.7,51.5,23.6 \mathrm{~cm}^{2}\right)$, fresh weight of shoot $(1.8,2.5,2.6 \mathrm{~g})$ dry weight of shoot $(0.4,0.7,0.6 \mathrm{~g})$ length of spike $(11.2,14.7,10.6 \mathrm{~cm})$, number 


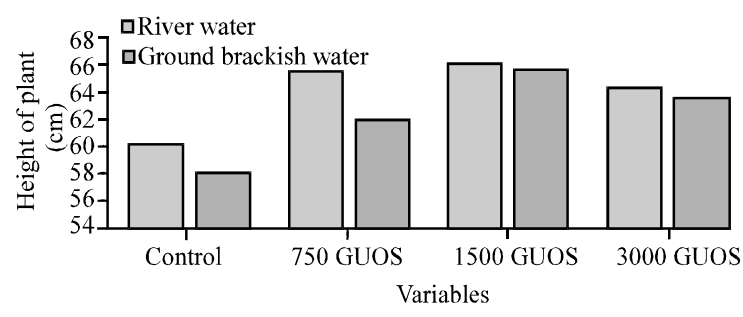

Fig. 1: Compared between magnetized ground and river water in height of plant $(\mathrm{cm})$

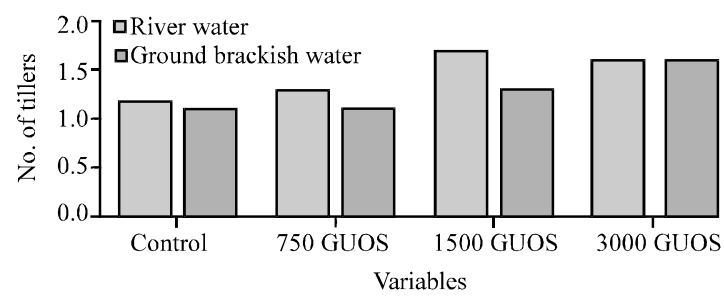

Fig. 2: Compared between magnetized ground and river water in number of tillers

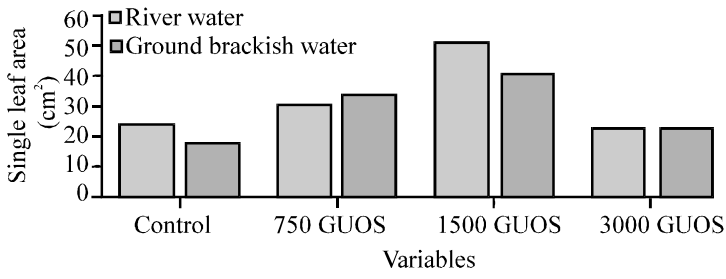

Fig. 3: Compared between magnetized ground and river water in single leaf of area

of floret per spike $(22.4,26,19.5)$, weight of spike $(0.8,1.2,0.8 \mathrm{~g})$, respectively. Ordinary ground brackish water and magnetized ground brackish water 750,1500 , 3000 are presented in Table 2. Irrigation with magnetized ground brackish water increased height of plant (62.0, $65.6,63.6 \mathrm{~cm})$, number of leaves $(4.8,4.9,4.5)$, number of tillers $(1.1,1.3,1.5)$, single leaf area $\left(33.9,40.5,19.4 \mathrm{~cm}^{2}\right)$, fresh weight of shoot $(2,2.6,2.7 \mathrm{~g})$ dry weight of shoot $(0.5,0.7,0.5 \mathrm{~g})$ length of spike $(10.5,11,10.5 \mathrm{~cm})$, number of floret per spike $(19.6,22,20.7)$, weight of spike $(0.8,0.9$, $0.8 \mathrm{~g})$, respectively.

In this investigation, irrigation with magnetic water in 1500 GUOS as compared to 750,3000 GUOS gave the better results in all growth characterized (Fig. 2-8) accepts height of plant $(\mathrm{cm})$ (Fig. 1). The effects of magnetic exposure on plants growth still require proper explanation. They may be the result of bioenergetics structural excitement causing cell pumping and enzymatic stimulation. In this research the stimulatory impact of magnetic water induced no significant marked between irrigation of magnetized river water and ground brackish

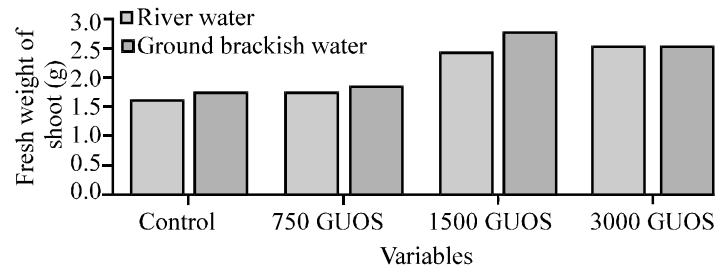

Fig. 4: Compared between magnetized ground and river water in fresh weight of shoot (g)

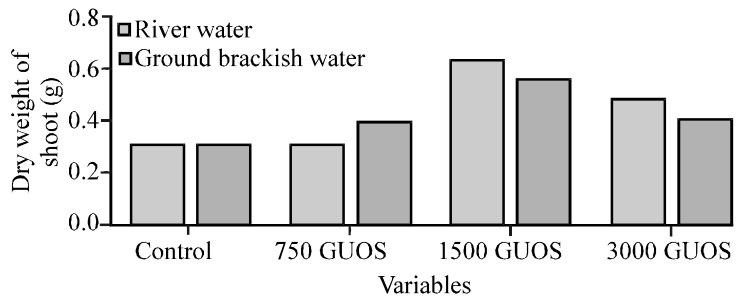

Fig. 5: Compared between magnetized ground and river water in dry weight of shoot $(\mathrm{g})$

water in all growth characterized (Fig. 1-8). May be also ascribed to the increasing of shoot and root growth which increase absorption and assimilation of nutrients is not correlates with the concentrations of the salts in water. Findings of these results also are in agreement with those obtained by (Reina et al., 2001) who found significance increase in the rate of water absorption accompanied with an increase in total mass of lettuce (Al-Jubouri and Jalal, 2012) whose agreements with this results. In the current study was increased in the shoots irrigated with magnetized water as compared to the ordinary water. Similar to our result (Mulook et al., 2011) found that irrigation with magnetic water increased WUE (Aladjadjiyan, 2010) observed that water productivity in celery and snow pea was increased in magnetic water treatment than that control.

In this study, magnetic water increased total biomass of wheat as compared to ordinary river water and ground brackish water. Similar, enhancing effect of magnetized irrigation water were reported on snow pea and chick pea (Grewal and Maheshwari, 2011) flax and lentil (Qados and Hozayn, 2010) and wheat (Hozayn and Qados, 2010). This improved growth may lead to an early canopy cover and a better competition against weeds and thus more efficient use of nutrients and irrigation water. Positive effects of magnetized water on growth of stem and leaf of wheat are very important, since, they appear to induce an improved capacity for nutrients and water uptake, providing greater physical support to the developing shoot. Better shoot growth might lead to better shoot systems throughout the life time of plants (De Souza et al., 2006). 


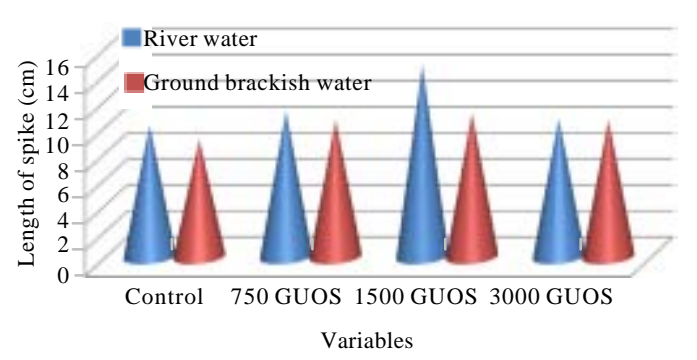

Fig. 6: Compared between magnetized ground and river water in length of spike $(\mathrm{cm})$

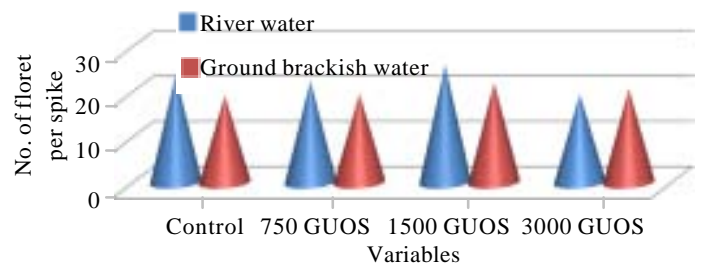

Fig. 7: Compared between magnetized ground and river water in number of floret per spike

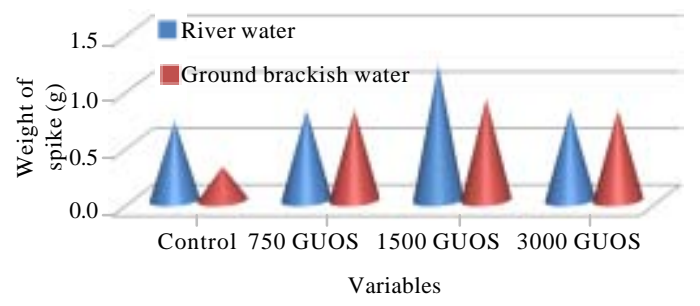

Fig. 8: Compared between magnetized ground and river water in weight of spike (g)

Moreover, the formation of new tillers in plants treated with magnetic water may be responsible for the stimulation of growth and promoters in treated plants (Qados and Hozayn, 2010a, b). In this respect (Celik et al., 2008), found that the increase in the percentage of plants regeneration is due to the effect of magnetic field on cell division and protein synthesis in paulownia node cultures (Shabrangi and Majd, 2009) concluded that biomass increasing needs metabolic changes particularly increasing protein biosynthesis.

It was found that irrigation with magnetized water increased leaf area in wheat compared to plant control. The enhancement in leaf area in the plants irrigated with magnetic water must have increased photosynthetic rates due to the greater interception of light and the greater amount of assimilates available for vegetative growth. Similar results were found by De Souza et al. (2006).
In this research the effect of magnetic water on the yield and yield component of wheat data in Table 1 and 2 cleared that magnetic water increased all yield characters over the untreated controls the percentage of increase reached to $3.89 \%$ in plants height. Generally, the stimulatory effect of magnetic treatment may be attributed to their role in increasing growth promoters (Table 1 and 2) consequently, increasing yield characters.

These results are in agreement with those obtained by Tian et al. (1991) who indicated that magnetic water increased yield of rice by $13.23 \%$. This was accompanied the stimulation effect of magnetic water on leaf chlorophyll content (Kordas, 2002) found that the exposure of green tops and root systems of wheat plants to magnetic water increased quantity of coarse floret by 10.6 and $6.3 \%$, respectively. Moreover, magnetic water was shown to induce fruit yield per shoot and average fruit weight (Celik et al., 2008). Exposure of shoots to magnetic water is highly effective in enhancing growth characteristics. This observation suggests that there may be resonance-like phenomena which increase higher yield (Vashisth and Nagarajan, 2008) and (Shabrangi and Majd, 2009) on chickpea and lentil, respectively. The present study showed that magnetic water had the greatest effect on shoot weight. It suggests that enhancement the growth of spikes and floret on spike was related to increasing of shoot growth which improved water and ions transmission. Ions in the cell have the ability to absorb magnetic energy corresponding to specific parameters related to their vibration and rotation energy sublevels. This phenomenon represents a kind of resonance absorption and could explain the stronger effect of applying definite values of magnetic field induction (Aladjadjiyan, 2010). The stimulatory effect of magnetized water on growth parameters may be attributed to the induction of cell metabolism and mitosi (Qados and Hozayn, 2010a, b). Improved magnetized water in the present study could help in the water resources conservation, particularly in arid and semi-arid regions.

\section{CONCLUSION}

Concerning the effects of magnetized water especially on wheat very limited researches were performed in Iraq, therefore, this study was conducted to determine the impact of magnetized water on some morphological and physiological traits of wheat.

\section{ACKNOWLEDGEMENT}

I would like to express deep gratitude to the University of Kufa, Faculty of Science and Department of 
Environmental Sciences for their assistance in collecting samples and analyzing the results in the Department of Environmental Sciences Laboratories.

\section{REFERENCES}

Al-Jubouri, A.E.A.M.A. and H.H. Jalal, 2012. Magnetically water treatment technology and its impact in the agricultural field. Msc Thesis, Department of Field Crop Sciences, Baghdad University, Baghdad, Iraq.

Aladjadjiyan, A., 2010. Influence of stationary magnetic field on lentil seeds. Intl. Agrophys, 24: 321-324.

Aladjadjiyan, A., 2012. Physical Factors for Plant Growth Stimulation Improve Food Quality. In: Food Production Approaches, Challenges and Tasks, Aladjadjiyan, A. (Ed.). InTech Process Automation Inc., Lahore, Pakistan, ISBN:978-953-307-887-8, pp: 145-168.

Celik, O., C. Atak and A. Rzakulieva, 2008. Stimulation of rapid regeneration by a magnetic field in Paulownia node cultures. J. Cent. Eur. Agric., 9: 297-304.

De Souza, A., D. Garci, L. Sueiro, F. Gilart and E. Porras et al., 2006. Pre-sowing magnetic treatments of tomato seeds increase the growth and yield of plants. Bio Electro Magn., 27: 247-257.

Grewal, H.S. and B.L. Maheshwari, 2011. Magnetic treatment of irrigation water and snow pea and chickpea seeds enhances early growth and nutrient contents of seedlings. Bioelectromagnetics, 32: 58-65.

Harichand, K.S., V. Narula and D. Raj, 2002. Effect of magnetic fields on germination, vigor seed yield of wheat. Seed Res., 30: 289-293.

Hozayn, M. and A.M.S.A. Qados, 2010. Magnetic water application for improving wheat (Triticum aestivum L.) crop production. Agric. Biol. J. North Am., 1: 677-682.

Kordas, L., 2002. The effect of magnetic field on growth, development and the yield of spring wheat. Pak. J. Environ., 11: 527-530.

Maheshwari, B.L. and H.S. Grewal, 2009. Magnetic treatment of irrigation water: Its effects on vegetable crop yield and water productivity. Agric. Water Manage., 96: 1229-1236.
Mostafazadeh-Fard, B., M. Khoshravesh, S.F. Mousavi and A.R. Kiani, 2011. Effects of magnetized water and irrigation water salinity on soil moisture distribution in trickle irrigation. J. Irrigation Drainage Engineering Am. Soc. Civil Eng., 137: 398-402.

Moussa, H.R., 2011. The impact of magnetic water application for improving common bean (Phaseolus vulgaris L.) production. N. Y. Sci. J., 4: 15-20.

Mulook, Al-Khazan, Batoul M. Abdullatif and A. Nabila, 2011. Effects of magnetically treated water on water status, chlorophyll pigments and some elements content of Jojoba (Simmondsia chinensis L.) at different growth stages. Afr. J. Environ. Sci. Technol., 5: 722-731.

Qados, A.M.S.A. and M. Hozayn, 2010a. Magnetic water technology, a novel tool to increase growth, yield and chemical constituents of lentil (Lens esculenta) under greenhouse condition. Am. Eur. J. Agric. Environ. Sci., 7: 457-462.

Qados, A.M.S.A. and M. Hozayn, 2010b. Response o f growth, yield, yield components and some chemical constituent of flax for irrigation with magnetized and tap water. World Applied Sci. J., 8: 630-634.

Reina, F.G., L.A. Pascual and I.A. Fundora, 2001. Influence of a stationary magnetic field on water relations in lettuce seeds, Part II: Experimental results. Bioelectromagnetics, 22: 596-602.

Shabrangi, A. and A. Majd, 2009. Effect of magnetic fields on growth and antioxidant systems in agricultural shoots. Proceedings of the International Conference on PIERS, March 23-27, 2009, Beijing, China, pp: 1142-1147.

Tian, W.X., Y.L. Kuang and Z.P. Mei, 1991. Effect of Magnetic Water on Seed Germination, Seedling Growth and Grain Yield of Rice. In: Field Crop Abstracts, Commonwealth Agricultural Bureaux and Commonwealth Bureau of Pastures and Field Crops (Ed.). Commonwealth Agricultural Bureaux, Wallingford, Oxfordshire, UK., pp: 044-07228.

Vashisth, A. and S. Nagarajan, 2008. Exposure of seeds to static magnetic field enhances germination and early growth characteristics in chickpea (Cicer arietinum L.). Biolectromagnetics, 29: 571-578. 